\title{
Incidence and outcome of sudden cardiac death in Split-Dalmatia County, Croatia
}

\author{
(D)Drago Rakić1*, \\ (DLeo Luetić , \\ (D) Velimir Pivac ${ }^{3}$, \\ (i) Ivana Cvitković ${ }^{4}$, \\ (1)Zvonko Rumboldt ${ }^{5}$
}

'Polyclinic for Internal Medicine and Pediatrics Dr Rakić, Split, Croatia ${ }^{2}$ Institute of Emergency Medicine of Split-Dalmatia County, Split, Croatia 3University Hospital Centre Split, Split, Croatia ${ }^{4}$ Cardiology practice $\mathrm{Dr}$ Cvitković, Split, Croatia ${ }^{5}$ University of Split School of Medicine, Split, Croatia
RECEIVED:

December 5, 2020

ACCEPTED:

December 18, 2020
KEYWORDS: cardiac arrest, Croatia, emergency medical service, resuscitation, sudden cardiac death. CITATION: Cardiol Croat. 2021;16(1-2):15. | https://doi.org/10.15836/ccar2021.15

*ADDRESS FOR CORRESPONDENCE: Drago Rakić, Poliklinika za internu medicinu i pedijatriju dr Rakić, Roosveltova 54, HR-21000 Split, Croatia. / Phone: 385-91-5477949 / E-mail: poliklinika.dr.rakic@hi.t-com.hr

ORCID: Drago Rakić, https://orcid.org/0000-0001-9064-2055 • Leo Luetić, https://orcid.org/0000-0001-9907-0401 Velimir Pivac, https://orcid.org/0000-0001-6726-0569 • Ivana Cvitković, https://orcid.org/0000-0002-9445-9415 Zvonko Rumboldt, https://orcid.org/0000-0002-6811-275X

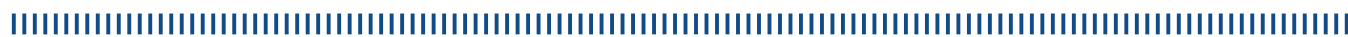

Introduction: Sudden cardiac death (SCD) is mostly defined as a natural death due to cardiovascular cause that occurs within one hour of the onset of symptoms. ${ }^{1}$ Out-of-hospital SCD frequency is underestimated because it reflects the cases treated by emergency medical services (EMS) only, which amounts to some $50-60 \%$ of the global incidence. Moreover, it is highly variable, ranging from 38 to over 84.7 per 100,000 inhabitants per year; in Croatia $62 / 100,000^{2}$ or some 9000 victims per year. SCD survival to hospital discharge is also widely variable, ranging from $0.3 \%$ to $20.4 \% .^{1,2}$ The aim of this study was to assess the SCD incidence and survival rate among the victims resuscitated by EMS in Split-Dalmatian County.

Methods: From the Split-Dalmatian County EMS electronic data base analyzed were all SCD case reports (Utstein forms) from January 1, 2017 to December 31, 2017. Data on etiology and outcome for hospitalized SCD individuals were extracted from patients' files, discharge letters and/or autopsy notes.

Results: During the investigated period there were 291 EMS treated victims of presumed SCD $(69 / 100,000)$. Sudden death mostly (68\%) happened at home, lay CPR on the spot was performed in 12 cases (4.1\%) only, with no instance of lay defibrillation. Hospitalized were 32 (11\%) such individuals, 21 surviving to hospital discharge (7.2\%).

Conclusion: The identified weak links in the survival chain must be improved, e.g. for low SCD survival rate - assure public access to lay defibrillation, such as "Start the Heart - Save the Life" program in Croatia; for lay defibrillation lack - provide as many AEDs as possible, form a network of devices, and educate a large number of volunteers; for the prevalent SCD occurrence at home - train family members of patients at elevated risk in CPR.

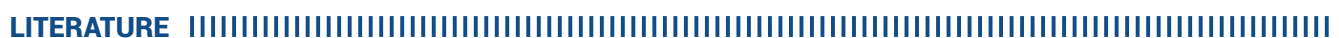

1. Priori SG, Aliot E, Blomstrom-Lundqvist C, Bossaert L, Breithardt G, Brugada P, et al. Task Force on Sudden Cardiac Death of the European Society of Cardiology. Eur Heart J. 2001 Aug;22(16):1374-450. https://doi.org/10.1053/euhj.2001.2824

2. Gräsner JT, Lefering R, Koster RW, Masterson S, Böttiger BW, Herlitz J, et al; EuReCa ONE Collaborators. EuReCa ONE-27 Nations, ONE Europe, ONE Registry: A prospective one month analysis of out-of-hospital cardiac arrest outcomes in 27 countries in Europe. Resuscitation. 2016 Aug;105:188-95. https://doi.org/10.1016/j.resuscitation.2016.06.004 